\title{
Polar bear denning distribution in the Canadian Arctic
}

\author{
Katie R. N. Florko ${ }^{1,2}\left(\right.$ D . Andrew E. Derocher ${ }^{3}$. C-Jae C. Breiter ${ }^{1} \cdot$ Maha Ghazal $^{4} \cdot$ Daryll Hedman $^{5}$. Jeff W. Higdon ${ }^{6}$. \\ Evan S. Richardson ${ }^{7} \cdot$ Vicki Sahanatien $^{3,8} \cdot$ Vicki Trim $^{5} \cdot$ Stephen D. Petersen ${ }^{1}$
}

Received: 16 September 2019 / Revised: 27 February 2020 / Accepted: 24 March 2020 / Published online: 2 April 2020 (c) The Author(s) 2020

\begin{abstract}
Declines in Arctic sea ice associated with climate change have resulted in habitat loss for ice-adapted species, while facilitating increased human development at higher latitudes. Development increases land-use and shipping traffic, which can threaten ecologically and culturally important species. Female polar bears (Ursus maritimus) and cubs are susceptible to disturbance during denning; a better understanding of denning habitat distribution may aid management. We compiled existing location data on polar bear denning ( $n=64$ sources) in Canada between 1967 and 2018, including traditional ecological knowledge (TEK) studies, government and consultant reports, peer-reviewed scientific articles, and unpublished data acquired through data-sharing agreements. We synthesized these data to create a map of known denning locations. Most coastal regions in northern Canada supported denning, but large areas exist where denning is unreported. Gaps remain in the knowledge of polar bear denning in Canada and filling these will aid the conservation and management of polar bears in a changing Arctic.
\end{abstract}

Keywords Ursus maritimus $\cdot$ Climate change $\cdot$ Denning $\cdot$ Habitat $\cdot$ Traditional ecological knowledge

\section{Introduction}

Climate change has led to sea ice loss that is projected to continue through the next century (Stroeve and Notz 2015). Spatio-temporal declines in sea ice have been linked to shifts in ice-adapted species' foraging (Sciullo et al. 2017), distribution (Derocher et al. 2011), movement (Yurkowski et al. 2016), and reproduction (Ferguson et al. 2017). Many sea ice changes (e.g., reduced duration, extent, thickness) that are considered negative for Arctic wildlife may allow increased

Electronic supplementary material The online version of this article (https://doi.org/10.1007/s00300-020-02657-8) contains supplementary material, which is available to authorized users.

Katie R. N. Florko

katieflorko@gmail.com

1 Conservation and Research Department, Leatherdale International Polar Bear Conservation Centre, Assiniboine Park Zoo, Winnipeg, MB R3P 2N9, Canada

2 Institute for the Oceans and Fisheries, University of British Columbia, Vancouver, BC V6T 1Z4, Canada

3 Department of Biological Sciences, University of Alberta, Edmonton, AB T6G 2E9, Canada

4 Department of Environment and Geography, University of Manitoba, Winnipeg, MB R3E 0W2, Canada human access and industrial development (Burgass et al. 2018). The combination of habitat loss and increased disturbance can have negative consequences for wildlife if not managed (e.g., Polfus et al. 2011; Plante et al. 2018). Given the pace of Arctic warming and human activities, identifying important habitats and establishing protected areas for ecologically and culturally important species will become increasingly important.

Polar bears (Ursus maritimus) have a circumpolar Arctic range relying on sea ice habitats for traveling, hunting, and mating (Amstrup 2003). Similarly, the distribution of maternal denning is reliant on suitable habitat. Pregnant females typically den in snow banks or peat deposits on land

5 Water Stewardship and Biodiversity Division, Wildlife and Fisheries Branch, Manitoba Agriculture and Resource Development, Thompson, MB R8N 1X4, Canada

6 Higdon Wildlife Consulting, Winnipeg, MB R3G 3C9, Canada

7 Wildlife Research Division, Science and Technology Branch, Environment and Climate Change Canada, Winnipeg, MB R3C 4W2, Canada

8 P.O. Box 1584, Iqaluit, Canada 
and less frequently on sea ice where snow has accumulated (e.g., Kolenosky and Prevett 1983; Durner et al. 2003). Polar bears are seasonal breeders: mating occurs in the spring and implantation is delayed until the autumn when pregnant females construct and enter dens (Harington 1968; Ramsay and Stirling 1988). Gestation, parturition, and lactation occur in the den over winter (Nelson et al. 1983). Maternity dens provide shelter from Arctic conditions (Ramsay and Stirling 1988). Premature exposure of altricial cubs or disturbance of denning bears can result in reproductive failure (Ramsay and Dunbrack 1986; Amstrup and Gardner 1994; Linnell et al. 2000). Due to this vulnerability, denning areas were identified in the 1973 Agreement on the Conservation of Polar Bears as requiring special attention (Prestrud and Stirling 1994) and are considered critical habitat to protect in land-use plans (e.g., North Baffin Regional Land Use Plan).

Threats to denning polar bears may come from human disturbance and/or natural events associated with climate change. Threats from northern development can include seismic surveys, building of ice roads, and environmental contaminants (e.g., Amstrup 1993; Kerr 2002; Nuijten et al. 2016). Anthropogenic activities are expected to increase in intensity over time (Laidre et al. 2015) and subsequently increase the complexity for management to mitigate risks to Arctic wildlife. Climate change-related impacts may also threaten polar bear denning habitat. For example, an increase in forest fire activity and permafrost melting in peat habitat can destroy den habitat (Richardson et al. 2007). Winter rain can cause den collapse (Clarkson and Irish 1991) and reduced snow depth have been suggested as emerging threats over the entire range (Derocher et al. 2004; Hezel et al. 2012). Assessing and predicting the risk associated with these threats necessitate information on the distribution of denning habitat used by pregnant female polar bears.

Numerous studies on polar bear maternity denning have been conducted across Canada, but most focus on specific populations. The distribution of polar bear denning is available for Alaska (Durner et al. 2010) and Svalbard (Andersen et al. 2012); however, a similar compilation does not exist for Canada. Successful conservation of species and their habitats are linked to stakeholder engagement and participation (e.g., Kainer et al. 2009). For polar bears, additional information is held within communities as traditional ecological knowledge (TEK; a component of Inuit Qaujimajatuqangit; Usher 2000). Incorporation of TEK in decision making is part of polar bear conservation in Canada (Peacock et al. 2011) and thus should be incorporated into the cumulative knowledge of a species.

Our objectives were to (1) review and compile existing information on polar bear denning areas in Canada in an accessible database and (2) create a comprehensive map of all known polar bear denning locations. An accessible database and comprehensive map of denning regions are useful for managers when identifying critical habitat for polar bears.

\section{Materials and methods}

\section{Data aggregation}

We located information sources on polar bear maternity denning throughout their range in Canada (Online Resource 1). Some polar bears use temporary dens (Harington 1968), but those were outside of the scope of this study and not included. Data sources included TEK studies, peer-reviewed literature, and government reports. We also obtained unpublished data from some jurisdictions. For each source, we collected metadata information on the publication, region (management unit), type of data (point or polygon), and the publication type (Survey, Knowledge, or Review; see Online Resource 1).

\section{Den map creation}

Information on polar bear denning areas, ranging from broad areas to locations of individual dens, were added to a geographic information system (GIS) database in ArcGIS ${ }^{\circledR} 10.3$ (ESRI Inc., Redlands, CA, USA). Data were available as follows: (a) map point data (location of a den on a map or GPS coordinates); (b) map polygon data (location of denning area provided on a map); (c) descriptive point data (a description of a point where a den was observed; and/or (d) descriptive polygon (a description of an area that supports denning). Map data ( $a$ and $b$ ) were geo-referenced into the GIS database. Descriptive data (c and d) were interpreted subjectively; we developed a series of protocols to limit subjectivity of the descriptive data (Online Resource 2). Each map that provided denning information was scanned and converted to a JPEG image, geo-referenced onto a GCS North_American_1983 map, and projected in the Canada Lambert Conformal Conic coordinate system. As precisely as possible, points and polygons representing dens or denning areas (respectively) were digitized using ArcGIS ${ }^{\circledR}$.

\section{Results}

We obtained denning location data from 64 different sources (Online Resource 1) that contributed 1593 den location points and 430 denning area polygons that we have presented on a map (Fig. 1). We found most of the coastal regions of the Canadian range of polar bears were identified as having dens. Denning was not uniformly distributed, with rare occurrences of denning in Nunavik (Quebec), Nunatsiavut (Labrador), and the western Canadian High-Arctic 


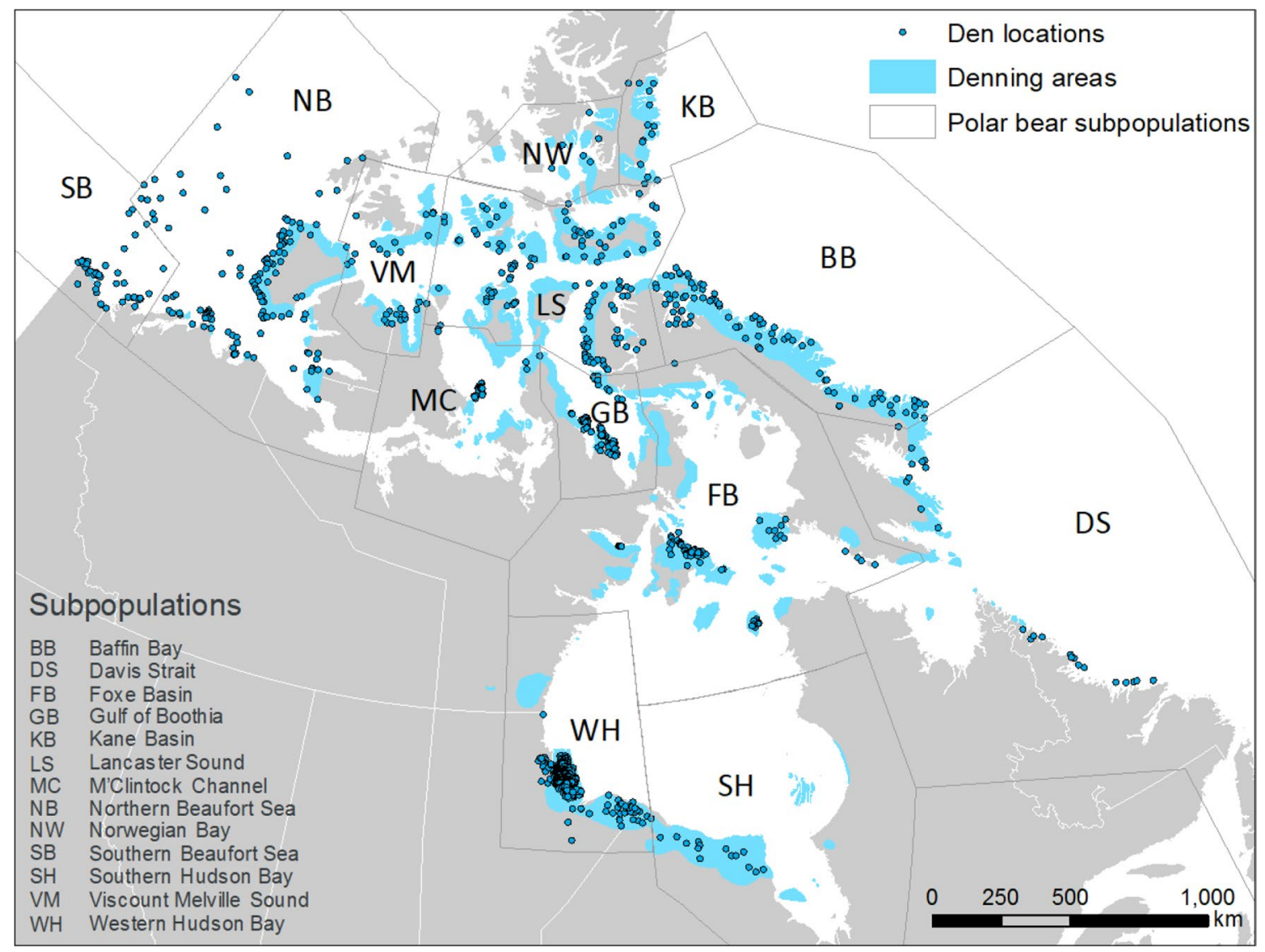

Fig. 1 Map of observed polar bear maternity dens (blue dots) and denning areas (blue shaded polygons) in the Canadian Arctic derived from traditional ecological knowledge (TEK) studies, government and consultant reports, peer-reviewed scientific articles, and unpublished data. These areas reflect published records of denning; areas

(Fig. 1). While most denning occurred on land (e.g., Clark et al. 1997; Richardson et al. 2005), there were numerous records of denning on pack-ice in the Beaufort Sea (e.g., Durner et al. 2010; Rode et al. 2018), and on land-fast ice throughout the Canadian Arctic Archipelago (e.g., Stirling et al. 1978; Ferguson et al. 2000).

\section{Discussion}

We provide a map of available polar bear denning records in Canada. High-density polar bear denning areas can be considered critical habitat and our compilation may provide conservation insights in the face of climate change and increased disturbance.

Polar bear denning was recorded in many coastal regions of the Canadian Arctic and sub-Arctic (Fig. 1), but the distribution ranged from areas of high density to areas with no reports of denning. On a fine scale, den habitat has been related to landscape features such as snow, peat banks, tree with no denning areas shown do not necessarily indicate that denning does not occur. Note the circles identify dens with coordinate data but each is scaled for visual purposes: the entire area underneath the circle does not necessarily represent denning areas

cover, topography, and aspect (Harington 1968; Kolenosky and Prevett 1983). Topography and aspect are especially important for the formation of stable snow drifts that will persist for the entire denning period (Liston et al. 2016). Land-fast ice is the preferred habitat for females emerging from dens (Pilfold et al. 2014) and den sites are possibly selected due to their proximity to spring hunting areas. Our results suggest denning habitat is more evenly distributed across much of the northern extent of the Canadian polar bear range, but is more patchy and concentrated in the southern extent of polar bears range (e.g., western and southern Hudson Bay). In Manitoba specifically, the large number of observed polar bear dens in Wapusk National Park (Fig. 1) may be due to specific habitat characteristics (e.g., concentration of suitable habitat).

Offshore polar bear denning primarily occurred on the land-fast ice throughout the Canadian Arctic Archipelago (Fig. 1); denning on offshore pack-ice was also recorded, and exclusively occurred in the Beaufort Sea. Monitoring activities in the Chukchi and Beaufort seas, extending into 
the western Canadian Arctic, have observed southward and eastward shifts in pack-ice den distribution (in some cases from sea ice to land), in response to reduced multiyear sea ice, increased unconsolidated ice, and increased duration of melt season (Fischbach et al. 2007; Olson et al. 2017). There were no published records of offshore pack-ice denning on other Canadian seascapes (e.g., Hudson Bay, Baffin Bay), perhaps because terrestrial denning is preferred, or sea ice is too unstable. Denning on sea ice in the Beaufort Sea may have resulted from historic terrestrial harvest pressure that depleted those females that denned on land (Stirling and Andriashek 1992) and the close proximity of multiyear sea ice over the continental shelf.

Reporting of polar bear denning was not uniform across the Canadian Arctic. In particular, we note three regions with sparse data: (1) Nunavik (Quebec); (2) Nunatsiavut (Labrador); and (3) the western Canadian High-Arctic. This is in spite of the presence of polar bear subpopulations (Fig. 1) that occupy adjacent marine areas. Although few den records suggests that data are missing, recent TEK reports provide information that denning occurs but do not identify high-density denning areas in these regions (e.g., Slavik 2013; IJS 2015; NMRWB 2018), suggesting that dens are dispersed over the landscape at low density. The information available on dens also reflects the intensity of research in various areas. For example, the Western Hudson Bay population has been extensively studied since the 1960s (Vongraven et al. 2018) with 14 publications/reports on polar bear denning, including repeated surveys for dens, and subsequently, a high density of den locations (e.g., Richardson et al. 2005).

While we recognize that polar bears may den in areas not identified by our research, the Canadian Arctic has been widely studied and by combining these data with TEK, we think that major denning areas have not been overlooked. Our analyses identified areas with low den numbers for which we were unable to determine if sampling effort or lack of use is the cause of these gaps. Therefore, environmental impact reviews should consider our data as a base to which local knowledge, recorded in the future, may be added.

A large portion of polar bear denning data $35 \%$ of sources), both historical and recent, was derived from publications of TEK. This highlights the importance of including and recording the knowledge of species held in indigenous communities (Usher 2000). TEK can cover large spatio-temporal scales, local perspectives, and incorporate pre-existing, but unrecorded data. As such, an interdisciplinary approach (i.e., combining TEK and survey data) to conservation biology facilitates partnerships, integrates local priorities, and provides insights into wildlife ecology.

The long-term observations of shifting den distribution in the Beaufort Sea (primarily offshore the Alaskan coast; Fischbach et al. 2007; Olson et al. 2017) and Baffin Bay and Kane Basin (Escajeda et al. 2018) stress the importance of polar bear den monitoring across the Canadian Arctic so shifts may be detected and managed accordingly. Continued or increased monitoring could provide insight to the response of female polar bears to habitat changes and increased human activity.

Acknowledgements This research was funded in part by World Wildlife Fund (WWF) Canada; the results and recommendations presented in this paper do not necessarily represent the official position of WWFCanada. We also gratefully acknowledge financial support from the Assiniboine Park Conservancy and Project Learning Tree. We thank Heather Penner for data compilation assistance, Geoff York for support during initial project work, and David Yurkowski and two anonymous reviewers for helpful comments on earlier versions of the manuscript.

Conflict of interest The authors declare that they have no conflicts of interest.

Open Access This article is licensed under a Creative Commons Attribution 4.0 International License, which permits use, sharing, adaptation, distribution and reproduction in any medium or format, as long as you give appropriate credit to the original author(s) and the source, provide a link to the Creative Commons licence, and indicate if changes were made. The images or other third party material in this article are included in the article's Creative Commons licence, unless indicated otherwise in a credit line to the material. If material is not included in the article's Creative Commons licence and your intended use is not permitted by statutory regulation or exceeds the permitted use, you will need to obtain permission directly from the copyright holder. To view a copy of this licence, visit http://creativecommons.org/licenses/by/4.0/.

\section{References}

Amstrup SC (1993) Human disturbances of denning polar bears in Alaska. Arctic 46:246-250

Amstrup SC (2003) The Polar Bear - Ursus maritimus. In: Feldhamer GA, Thompson BC, Chapman JA (eds) Wild Mammals of North America: biology, management, and conservation. Johns Hopkins University Press, Baltimore, pp 587-610

Amstrup SC, Gardner C (1994) Polar bear maternity denning in the Beaufort Sea. J Wildl Manag 58:1-10

Andersen M, Derocher AE, Wiig Ø, Aars J (2012) Polar bear (Ursus maritimus) maternity den distribution in Svalbard, Norway. Polar Biol 35:499-508

Burgass MJ, Milner-Gulland EJ, Stewart Lowndes JS, O’Hara C, Afflerbach JC, Halpern BS (2018) A pan-Arctic assessment of the status of marine social-ecological systems. Reg Environ Change 19:293-308

Clark DA, Stirling I, Calvert W (1997) Distribution, characteristics, and use of earth dens and related excavations by polar bears on the Western Hudson Bay lowlands. Arctic 50:158-166

Clarkson PL, Irish D (1991) Den collapse kills female polar bear and two newborn cubs. Arctic 44:83-84

Derocher AE, Lunn NJ, Stirling I (2004) Polar bears in a warming climate. Integr Comp Biol 44:163-176

Derocher AE, Andersen M, Wiig Ø, Aars J, Hansen E, Biuw M (2011) Sea ice and polar bear den ecology at Hopen Island, Svalbard. Mar Ecol Prog Ser 441:273-279 
Durner GM, Amstrup SC, Fischbach AS (2003) Habitat characteristics of polar bear terrestrial maternal den sites in northern Alaska. Arctic 56:55-62

Durner GM, Fischbach AS, Amstrup SC, Douglas DC (2010) Catalogue of polar bear (Ursus maritimus) maternal den locations in the Beaufort Sea and neighboring regions, Alaska, 1910-2010. U.S. Geological Survey, Data Series 568. pp 14

Escajeda E, Laidre KL, Born EW, Wiig Ø, Atkinson S, Dyck M, Ferguson SH, Lunn NJ (2018) Identifying shifts in maternity den phenology and habitat characteristics of polar bears (Ursus maritimus) in Baffin Bay and Kane Basin. Polar Biol 41:87-100

Ferguson SH, Taylor MK, Rosing-Asvid A, Born EW, Messier F (2000) Relationships between denning of polar bears and conditions of sea ice. J Mammal 81:1118-1127

Ferguson SH, Young BG, Yurkowski DJ, Anderson R, Willing C, Nielsen O (2017) Demographic, ecological, and physiological responses of ringed seals to an abrupt decline in sea ice availability. PeerJ 5:e2957

Fischbach AS, Amstrup SC, Douglas DC (2007) Landward and eastward shift of Alaskan polar bear denning associated with recent sea ice changes. Polar Biol 30:1395-1405

Harington CR (1968) Denning habits of the polar bear Ursus maritimus. Canadian Wildlife Service Report Series 5:2-30

Hezel PJ, Zhang X, Bitz CM, Kelly BP, Massonnet F (2012) Projected decline in spring snow depth on Arctic sea ice caused by progressively later autumn open ocean freeze-up this century. Geophys Res Lett 39:L17505

Inuvialuit Joint Secretariat (IJS) (2015) Inuvialuit and Nanuq: A polar bear Traditional Knowledge study. Inuvialuit Settlement Region, Joint Secretariat, p 304

Kainer KA, DiGiano ML, Duchelle AE, Wadt LH, Bruna E, Dain JL (2009) Partnering for greater success: local stakeholders and research in tropical biology and conservation. Biotropica 41:555-562

Kerr RA (2002) A warmer arctic means change for all. Science 297:1491-1492

Kolenosky GB, Prevett JP (1983) Productivity and maternity denning of polar bears in Ontario. Int Conf Bear Res Manage 5:238-245

Laidre KL, Stern H, Kovacs KM, Lowry L, Moore SE, Regehr EV, Ferguson SH, Wiig Ø, Boveng P, Angliss RP, Born EW (2015) Arctic marine mammal population status, sea ice habitat loss, and conservation recommendations for the $21^{\text {st }}$ century. Cons Biol 29:724-737

Linnell JD, Swenson JE, Andersen R, Barnes B (2000) How vulnerable are denning bears to disturbance? Wildlife Soc B 28:400-413

Liston GE, Perham CJ, Shideler RT, Cheuvront AN (2016) Modeling snowdrift habitat for polar bear dens. Ecol Model 320:114-134

Nelson RA, Folk GE Jr, Pfeiffer EW, Craighead JJ, Jonkel CJ, Steiger DL (1983) Behavior, biochemistry, and hibernation in black, grizzly, and polar bears. Bears 5:284-290

Nuijten RJM, Hendriks AJ, Jenssen BM, Schipper AM (2016) Circumpolar contaminant concentrations in polar bears (Ursus maritimus) and potential population-level effects. Environ Res 151:50-57

Nunavik Marine Regional Wildlife Board (NMRWB) (2018) Nunavik Inuit Knowledge and Observations of Polar Bears: Polar bears of the Southern Hudson Bay sub-population. Prepared by Basterfield M, Breton-Honeyman K, Furgal C, Rae J, O'Connor M. p 73

Olson JW, Rode KD, Eggett D, Smith TS, Wilson RR, Durner GM, Fischbach A, Atwood TC, Douglas DC (2017) Collar temperature sensor data reveal long-term patterns in southern Beaufort Sea polar bear den distribution on pack ice and land. Mar Ecol Prog Ser 564:211-224

Peacock E, Derocher AE, Thiemann GW, Stirling I (2011) Conservation and management of Canada's polar bears (Ursus maritimus) in a changing Arctic. Can J Zool 89:371-385

Pilfold NW, Derocher AE, Richardson E (2014) Influence of intraspecific competition on the distribution of a wide-ranging, non-territorial carnivore. Glob Ecol Biogeogr 43:425-435

Plante S, Dussault C, Richard JH, Côté SD (2018) Human disturbance effects and cumulative habitat loss in endangered migratory caribou. Biol Conserv 224:129-143

Polfus JL, Hebblewhite M, Heinemeyer K (2011) Identifying indirect habitat loss and avoidance of human infrastructure by northern mountain woodland caribou. Biol Conserv 144:2637-2646

Prestrud P, Stirling I (1994) The International Polar Bear Agreement and the current status of polar bear conservation. Aquat Mamm 20:113-124

Ramsay MA, Dunbrack RL (1986) Physiological constraints on lifehistory phenomena: the example of small bear cubs at birth. Am Nat 127:735-743

Ramsay MA, Stirling I (1988) Reproductive biology and ecology of female polar bears (Ursus maritimus). J Zool 214:601-634

Richardson ES, Stirling I, Hik DS (2005) Polar bear (Ursus maritimus) maternity denning habitat in western Hudson Bay: a bottom-up approach to resource selection functions. Can J Zool 83:860-870

Richardson E, Stirling I, Kochtubajda B (2007) The effects of forest fires on polar bear maternity denning habitat in western Hudson Bay. Polar Biol 30:369-378

Rode KD, Olson J, Eggett D, Douglas DC, Durner GM, Atwood TC, Regehr EV, Wilson RR, Smith T, St. Martin M (2018) Den phenology and reproductive success of polar bears in a changing climate. J Mammal 99:16-26

Sciullo L, Thiemann GW, Lunn NJ, Ferguson SH (2017) Intraspecific and temporal variability in the diet composition of female polar bears in a seasonal sea ice regime. Arctic Sci 3:672-688

Slavik DVW (2013) Knowing Nanuut: Bankslanders knowledge and indicators of polar bear population health. MSc Thesis. Department of Resource Economics and Environmental Sociology, University of Alberta, Edmonton, p 190

Stirling I, Andriashek D (1992) Terrestrial maternity denning of polar bears in the eastern Beaufort Sea area. Arctic 45:363-366

Stirling I, Calvert W, Schweinsburg R, Kiliaan HPL (1978) Population ecology of the polar bear along the proposed Arctic Islands gas pipeline route. Environmental Management Service, Department of Environment, Edmonton, p 71

Stroeve J, Notz D (2015) Insights on past and future sea-ice evolution from combining observations and models. Glob Planet Change 135:119-132

Usher PJ (2000) Traditional ecological knowledge in environmental assessment and management. Arctic 53:183-193

Vongraven D, Derocher AE, Bohart AM (2018) Polar bear researchhas science helped conservation? Environ Rev 26:358-368

Yurkowski DJ, Semeniuk CA, Harwood LA, Rosing-Asvid A, Dietz R, Brown TM, Clackett S, Grgicak-Mannion A, Fisk AT, Ferguson SH (2016) Influence of sea ice phenology on the movement ecology of ringed seals across their latitudinal range. Mar Ecol Progr Ser 562:237-250

Publisher's Note Springer Nature remains neutral with regard to jurisdictional claims in published maps and institutional affiliations. 